\title{
The Effect of Moderate Intensity Physical Activity on Ureum and Creatinine Serum in Untrained Male Students
}

\author{
Rika Nailuvar Sinaga ${ }^{1}$, Marsal Risfandi ${ }^{2}$, Novita Sari Harahap ${ }^{3}$, Fajar Apollo Sinaga ${ }^{4}$ \\ \{ulva.sinaga@unimed.ac.id ${ }^{1}$ \} \\ Teaching Staff of Sports Science Faculty Universitas Negeri Medan, Indonesia ${ }^{1,2.3,4}$
}

\begin{abstract}
Exercise induces profound changes in the renal hemodynamics and protein excretion. Ureum and creatinine levels can be used to assess whether renal function is still working properly or not. Ureum and creatinine levels can be affected by physical activity because ureum and creatinine are products of protein metabolism in skeletal muscle. The purpose of this study was to see the effect of moderate intensity physical activity on ureum and creatinine serum in untrained male students. This research is a preexperimental study with the design of one group pretest-posttest. The sample in this study were ten untrained male students taken by purposive sampling. Physical activity protocol is running on a treadmill for 60 minutes with an intensity of 60-75 percent of maximum heart rate reserve (MHR). Blood samples were taken to measure ureum and creatinine before and after the physical activity. Data were analyzed by paired T-test and Wilcoxon test. This study showed that the average results of ureum had a significant decrease and mean results of creatinine showed a significant increase. Based on these results we can conclude that the moderate intensity of physical activity on a treadmill reduces ureum and increases creatinine in untrained male students.
\end{abstract}

Keywords: Ureum, Creatinine, Renal, Moderate Intensity Physical Activity.

\section{Introduction}

During physical exercise there is an increase in oxygen consumption throughout the body, especially in muscle fibers (Ji, 1999), but blood flow and metabolism decrease significantly in the kidneys during exercise (Radak et al, 2013). This causes changes in the glomerular filtration rate and reabsorption mechanism which ultimately affect the marker of kidney function (Bijeh and Farahati, 2013). Kidney function tests can be done to see how the kidneys cleanse the blood from metabolic waste products that will poison the body, including urea and creatinine tests (Baniata et al, 2009).

Ureum is a residual product from the metabolism of proteins produced by the liver through the urea cycle. The urea cycle consists of five reactions, two occur in the mitochondria and three in the cytosol. The resulting urine will be transported in the blood to the kidneys to be secreted in the urine.Ureum is passively reabsorbed from the renal tubules but much less than chloride ions. When water is reabsorbed in the tubules (by osmosis along with sodium reabsorption), the urea concentration in the tubular lumen increases.This results in a concentration gradient that causes urea reabsorption.However, the urea cannot enter the tubules as much as water.Therefore, approximately one half of the urea which is filtered 
through glomerular capillaries will be passively reabsorbed from the tubules. The remaining urethra will enter the urine, causing the kidneys to excrete large amounts of this metabolic waste product(Guyton \& Hall, 2008).

Creatinine is a product that results from the breakdown ofcreatine phosphate in the muscles that is constantly produced by the body. During the change in creatine to phosphocreatine reactions catalyzed by creatine kinase spontaneous conversion to creatinine can occur. Creatinine is filtered from the blood by the kidneys. Serum creatinine changes during physical activity depend on the type, intensity and time of exercise.

Several studies have been conducted to see the effect of physical activity on kidney function. For an et al., (2003) found that the short-term effects of marathon training increased creatinine and blood urea nitrogen (BUN). Aerobic exercise for 12 weeks decreases creatinine levels and increases glomerular filtration rates in men and women (Straznicky et al, 2011). According to Warburton et al., (2002) concentrations of urea and creatinine increased after prolonged strenuous exercise in which this increase was associated with decreased renal blood flow and glomerular filtration rate, increased protein catabolism and creatinine release due to muscle work. Based on this background the researcher was interested in seeing the effect of moderate intensity physical activity on the concentration of urea and serum creatinine in untrained male students.

\section{Subjects and Methods}

This research is a pre-experimental study with one group pretest-posttest research design. The subjects in this study were male students aged 19-22 years with an average age of 20.5 years as many as 10 people. Before starting the research the subjects filled out the approval sheet into a sample. The subjects is not taking drugs, has no metabolic disease and is in good health tested by a doctor. Prior to the study the subjects first conducted intensity physical activity while using a treadmill according to the ability of the sample to determine the time to do physical activity. The results obtained when doing physical activity for one hour. The intensity used is $60-75 \%$ of the maximum pulse.

Blood is taken before and after physical activity and then measured in a laboratory using a Spectrophotometer Microlab 300 with a colorimetric method for uruem examination and the Jaffe method for creatinine examination. All data analysis was conducted by using SPSS 19 software. The obtained data were tested by paired T-test andWilcoxon test. Differences were considered significant at $\mathrm{p}<0,05$.

\section{Results}

This study aims to see the effect of moderate intensity physical activity on the concentration of urea and serum creatinine in untrained male students. From the results of the study obtained differences in the concentration of urea and creatinine as shown in Table 1.

Table 1. Differences in concentrations of urea and creatinine in untrained male students.

\begin{tabular}{cccccc}
\hline Variable & Group & $\mathrm{N}$ & Mean & Std. Deviation & $p$ value \\
\hline Ureum & Pretest & 10 & 36,08 & 2,47 & 0,007 \\
mg/dl & Postest & 10 & 19,67 & 7,77 & \\
Creatinine & Pretest & 10 & 0,97 & 0,12 & 0,039 \\
mg/dl & Postest & 10 & 1,10 & 0,13 & \\
\hline
\end{tabular}


From the results in Table 1, it is known that the average urea before getting physical activity with moderate intensity is higher than after getting physical activity. In the Wilcoxon test obtained $\mathrm{p}$ value $=0.007$ which means there are significant differences in the average serum urea in untrained male students. Average creatinine before getting physical activity with moderate intensity is lower than after getting physical activity. In the T-paired test obtained $\mathrm{p}$ value $=0.039$ which means there is a significant difference in the average serum creatinine in untrained male students

\section{Discussion}

The results showed a significant decrease in serum urea concentration, the same result was also found by Bijeh and Farahati, (2013) that BUN concentrations experienced a nonsignificant decrease in untrained middle-aged women who received aerobic exercise for six months, meaningless decline. It relates to training programs and types of activities and environmental conditions and the human race. Sokal et al (2013) found that urea concentrations decreased in subjects who did physical exercise and recovery on earthed compared to un-earthed. According to them earthing during exercise inhibits liver protein catabolism or increases renal urea excretion. Different results were found by Baniata et al (2009) that urea levels experienced a significant increase in Jordanian top athletes who received aerobic and anaerobic training.

Creatinine concentration increased significantly in this study. Similar results were found by Priest et al., (1982) that creatinine increased significantly in white men who received physical activity in the form of "mini-marathons". Bijeh and Farahati., (2013) found that creatinine levels experienced an insignificant increase in middle-aged, untrained women who received aerobic exercise for six months.

Baniata et al.,(2009) found that creatinine concentrations increased significantly in Jordanian top athletes who received aerobic and anaerobic exercise. Morales et al., (2013) found that serum creatinine levels increased significantly in male street runners who ran for 6 kilometers. According to Warburton et al.,(2002) creatinine release from contracting muscles, decreased blood flow in the kidneys and decreased glomerular filtration rate and dehydration cause an increase in plasma creatinine concentration.

\section{Conclusion}

Based on these results we can conclude that the moderate intensity of physical activity on a treadmill reduces ureum and increases creatinine in untrained male students.

\section{References}

[1] Baniatan A, Manse K, Aburjai T, Adeeb S, Al-Gazzawi M., 2009. Biochemical factors relevant to kidney functions among Jordanian top athletes. Sci. Res. Essays. Vol 4(5) pp. 426-431.

[2] Bijeh N, Farahati S. 2013. The Effect of Six Months of Aerobic Training on Renal Function Markers in Untrained Middle-Aged Woman. International Journal of Sport Studies. Vol.3(2). 218-224.

[3] Foran S, Lewandrowski K, Kratz A., 2003. Effects of exercise on laboratory test result. Laboratory medicine. Vol 34(10):736-742.

[4] Guyton, A. C., dan Hall, J.E. 2008. Fisiologi Kedokteran. (Terjemahan). Jakarta: Penerbit Buku Kedokteran EGC. 
[5] Ji, L.L.,1999. Antioxidants and Oxidative stress in exercise. Society for Experimental Biology and Medicine, 283: 292.

[6] Morales AP, Maciel RN, Jorge FS, Neto NTA, Cordeiro DC, Viana MAS, Oliveira CJL.,2013. Changes in serum creatinine, uric acid, creatine kinase and glomerular filtration in street runners. RBCDH, 15(1):71-81.

[7] Priest J B, Oei T O, Moorehead W R. 1982. Exercise- Induced Changes inCommon Laboratory Tests. A.J.C.P. Vol 77(3). 285-289.

[8] Radak, Z., Zhao, Z., Koltai, E., Ohno, H., Atalay, M., 2013. Oxygen Consumption and Usage During Physical Exercise: The Balance Between Oxidative Stress and ROS-Dependent Adaptive Signaling. Antioxidants \& Redox Signaling, Vol. 18, No. 10,1208-1246.

[9] Sokal P, Jastrzebski Z, Jaskulska E, Sokal K, Jastrzebska M, Radziminski L, Dargiewicz R, Zielinski P., 2013. Differences in blood urea and creatinine concentrations in earthed and unearthed subjects during cycling exercise and recovery. Evidance-Based Complementary and Alternative Medicine. Article ID 382643 pp. 1-6.

[10] Straznicky NE, Grima MT, Lambert EA, Eikelis N, Dawood T, Lambert GW, et al., 2011. Exercise augments weight loss induced improvement in renal function in obese metabolic syndrome individuals. J Hypertens, 29(3):553-564.

[11] Warbuton DER, Welsh RC, Haykowsky MJ, Taylor DA, Humen DP., 2002. Biochemical changes as a result of prolonged strenuous. Br J Sport Med. 36:301-30 